\title{
Comparative Analysis of The Effects of Microfinance Services on The Technical Efficiency of Cassava Farmers in Kogi State, Nigeria: A Stochastic Frontier Production Function Approach
}

\author{
David, Adama Monday ${ }^{1}$ \\ Okoye, Chukwuemeka Uzoma ${ }^{2}$ \\ Department of Agricultural Economics, University of Nigeria, Nsukka, Nigeria.
}

\begin{abstract}
Nigeria is the largest producer of cassava in the world but its output per hectare fall short of what is obtainable in other countries of the world. Besides, cost of cassava production per ton is very high. This study examined the effects of microfinance services (MFSs) on the technical efficiency (TE) of cassava farmers in Kogi Sate, Nigeria; using cross-sectional data. The study used a two-stage random and purposive/proportional sampling technique for the selection of 240 cassava farmers. 120 of these farmers were clients of microfinance institutions (CMFIs) while the rest 120 were non client of microfinance institutions (NCMFIs). The analytical techniques involve the estimation of TE following one-step approach of Maximum Likelihood Estimation (MLE) procedure available in FRONTIER 4.1. Various tests of statistics were carried out, including generalized likelihood-ratio test for selection of the preferred model, z-test to determine the significance of the differences in technical efficiencies between the two groups of cassava farmers, $t$-test for testing the significance of each of the microfinance variables and socio-economic characteristics in the inefficiency model of cassava farming in the area. However, the maximum likelihood estimates for the parameters of the stochastic frontier production function (preferred models) revealed that land and cassava stems were significant inputs for CMFIs during access to MFSs cassava farmers. Land, fertilizer and cassava stems were significant for NCMFI cassava farmers. The mean TE revealed that CMFI were more technically efficient than the NCMFI. More so, CMFIs were more technically efficient during access to MFSs. The Amount of microcredit used and access to insurance policy were statistically significant and consistent with the a priori expectations. The z-tests revealed that CMFI cassava farmers were more efficient during access to microfinance services and as well more efficient than the NCMFI.
\end{abstract}

Keywords: stochastic frontier, technical efficiency, inefficiency, microfinance services, effects, Nigeria.

\section{Introduction}

Cassava (Manihot spp) is one of the most important crops in Nigeria. Nigeria is presently ranked the largest producer of cassava in the world, with an estimated annual output of $36-43$ million metric tones per annum, grown on 4,118,000 hectares of land. Nigeria also accounts for about 35 per cent of the total output in Africa (FAOSTAT, 2005; Phillip et al 2004; Ezedinma et al 2006). The North Central Zone of Nigeria produces over 7 million metric tones of cassava in which Kogi State ranks first with an annual output of about 2.666 million metric tones, grown on 200,750 hectares of land (PCU, 2003; IITA, 2004; KSADP, 2007). Cassava is inexpensive to grow and has the ability to yield well even in poor soils (CBN, 2004), with a potential yield of 80 tonnes per hectare (FAO, 2002). Due to these prospects, government effort has been to make cassava an engine of growth in Nigeria (Ezedinma et al 2006). In Kogi State, government established Kogi State Agricultural Development Trust Fund (KSADTF) an agency that monitor the activities of farmers, MFIs, farmers cooperatives and as well encouraged farmers (including cassava farmers) to source loans from Microfinance Banks, Cooperative Organizations, Nigerian Agricultural Cooperative and Rural Development Bank (NACRDB), and commercial banks among others (KSADTF, 2007).

Despite government, research and extension service efforts in cassava production, the outputs per hectare falls below what is obtainable in other parts of the world. According to IFPRI (2001), the average output per hectare in Nigeria is 11,691 kg against 79,230 kg in West Asia / North Africa and 32,652 kg in South East / East Asia. In addition, Nigeria takes a small proportion of about $0.001 \%$, of the world cassava export market, as against Thailand which accounts for 80\% (Oyewole and Phillips, 2006; Prakash, 2007). Also, the differences in the cost of production of between 104 US dollars/ton in Nigeria against 21 US dollars/ton in Thailand reflect the difficulties in cassava production in Nigeria (Oyewole and Phillip, 2006). The major problem militating against cassava production among small scale farmers in Nigeria is lack of access to finance and its allocation (SMEC, 2008; Syngenta, 2008). Lack of adequate access credits or microfinance services is believed to have significant 
negative consequences for various aggregate and household-level outcomes, including technology adoption, agricultural productivity and efficiency, food security, nutrition, health, and overall household welfare.

Microfinance is the term given to small-scale financial services for the poor who are cut off from the mainstream credit (UNIFAD, 2005). It covers a broad range of financial services including micro loans, deposits and payment services, savings mobilization, insurance, training and advisory services and encourages group and co-operative formation, information and communication technology (ICT) among the poor and low-income households as well as their enterprises (NACRDB, 2002; Qayyum and Ahmed, 2006; IFAD, 2007) In spite of its growing importance, providing microfinance services remains a big challenge because of the risks involved and the type of credit that farmers need (UNIFAD, 2005). Besides, it they are also encumbered with problems of loan default and low repayment, loan diversion, inability of farmers to access product market, lack of education and health care, among other constraints of resource use and productivity (Pederson, 2003).

Availability and accessibility of microfinance could enhance the economic efficiency of a cassava farmer. For a cassava farmer to be economically efficient, technical efficiency is a prerequisite. Technical efficiency is the maximization of the ratio of output to input in the production process (Arene, 2008). It is also defined as the ability of a firm to produce a given level of output with a minimum level of input under a given technology (Olayide and Heady, 1982). Improved access to credit or microfinance services may raise both technical and allocative efficiency in the agricultural sector (Abdulai and Huffman, 1998). Among cassava farmers it is expected to raise their level of technical efficiency by allowing them adopt capital-intensive methods of production. It can also raise their allocative efficiency by allowing them to substitute non - market inputs with market inputs and increase their ability to bear risks as well as increase the net revenue obtained from fixed inputs and market conditions.

Several studies have been carried out on the efficiency of resource use in agricultural production (Ike and Arutghor, 2005; Nwosu, 2005; Ajibefun, 2006 ; Ajibefun , Battese and Daramola ,2002; Ajibefun, 2007; Nghiem, Coelli and Rao, 2007; Ogundele and Okoruwa, 2006 ; Ogundari, 2006; Aye and Oboh, 2006; Ayeh, Oboh and Biam, 2006; Etim and Udoh, 2006; Chavas and Aliber, 1993; Kondoun, 2005. None of these studies has looked into measuring the effect of microfinance services on the technical efficiency of cassava farmers in Kogi State. Although, Asogwa, Umeh and Ater (2006) attempted to analyze technical efficiency determinants among cassava farmers in Benue State focused on the socio-economic variables which they discovered to have positive effect on the technical efficiency of the farmers, the major drawback in this study is that it did not includes variables of microfinance services; Qayyum and Ahmad (2006), in their research on the efficiency and sustainability of microfinance institutions in south Asia focused purely on the efficiency and sustainability of these institutions which they found to vary from region to region based on some indicators such as the number of active borrowers, personnel size, gross loan portfolio, average loan balance and financial ratios. The major drawback of their study is that it did not include the impact on the farmers of services that microfinance institutions rendered. Also, Chaovanapoonphol, Battese and Chang (2005), in their study attempted to measure the effect of rural financial services on the technical efficiency of rice farmers in Northern Thailand using stochastic frontier production function (SFPF), with maximum likelihood approach in which the loans received, age, level of education, experience and land area were discovered to have significant effect. The major drawback in their study was that emphasis was only on the impact of loans received by farmers without studying the impact of other services rendered to the farmers by these institutions. This paper therefore presents the results of an empirical study to see how microfinance services influence the technical efficiency of cassava farmers in cassava production as major and most important staple food in the area and enhance their competitiveness in Kogi State, Nigeria.

\section{Materials And Methods}

\section{Study Area}

The study area is Kogi State. It is located in the north central zone of Nigeria, approximately between latitudes $6^{0} .33^{\prime \prime}$ and $8^{0} .44^{\prime \prime} \mathrm{N}$ and longitudes $5^{0} .22^{\prime \prime}$ and $7^{0}$. The state, which has its capital at Lokoja, has a total land area of 28,312.64 square kilometers. Kogi State shares boundary with Niger, Nassarawa and Federal Capital Territory-Abuja to the North, with Benue to the east and with Enugu, Anambra, Edo, Ondo, Ekiti, and Kwara States to the South and West (KSADP, 1995). The state has a total population of about 3,278,487 (NPC, 2006), with 172,000 farm families. About seventy per cent of this population live in the rural areas and engage in agricultural production (KSADP, 1995).

Kogi State is heterogeneous in terms of its ethnic and geographical compositions. Ethnically, it has such groups as Igala, Ebira, Okun, Yoruba, and Nupe, forming the dominant tribes. There are many other smaller ethnic groups in the state. People from these ethnic groups inhabit twenty-one Local Government Areas in which the state is administratively divided. These are Adavi, Ankpa, Ajaokuta, Bassa, Dekina, Yagba-east, Yagba-west, Idah, Ijumu, Kabba/bunu, Kogi, Koto-karfe, Ofu, Okehi, Okene, Olamaboro, Ibaji, Mopamuro, Ogori Mangogo and Igalamela Odolu local government areas. Geographically, Kogi State is characterized with 
low and high lands. In low land areas are extrusive plains, alluvial and swampy features and these occur in areas along Niger and Benue valleys. Areas of high elevations are found in most parts of the state (KSADP, 1995).

\section{Sampling Technique}

For the purpose of this study, a two-stage random sampling methods was used for selecting respondents. Firstly, random sampling technique was adopted for selecting two (2) local government areas from each of the four (4) agricultural zone making eight (8) local governments in all. The L.G.As are Yagba - East, Kaba - bunu, Ankpa, Omala, Adavi, Kogi, Ofu and Olamaboro. Secondly, fifteen (15) cassava farmers who were clients of CMFIs were randomly selected from each of the 8 L.G.As. Also fifteen (15) cassava farmers who were non-clients of NCMFIs were purposively/proportionately selected from each of the 8 L.G.As, making a total of 240 respondents.

\section{Methods of Data Collection}

Data for this study were obtained from both primary and secondary sources. Primary data were collected through field survey by the researcher using structured questionnaires / interview schedule with the help of some extension staff of the KSADP of the four agricultural zones of the state. In addition, eight research assistants who are indigenes of the areas, one from each L.G.As that was randomly selected, were trained and used to assist in data collection. The field survey data focused on obtaining input-output data of two production seasons, i.e before access and during access to MFIs such as output of cassava in $\mathrm{kg}$, the area of land in hectares, total labour (family/non family) used in man-days, fertilizer used in $\mathrm{kg}$ (or bags i.e. $50 \mathrm{~kg} / \mathrm{bag}$ ), other agrochemical used (e.g. herbicides and insecticides) used in $\mathrm{kg}$ and some farmers specific variables like family size, educational status of the household head (year of schooling), experience of the head of household in years, level of microfinance accessibility, variables on microfinance services such as volume of loans received in naira, volumes of deposits (savings) made in naira, number of training and advisory services, access to information and technology services, access to insurance policy, microfinance services rendered to the farmers, total amount of microcredit obtained, amount of microcredit used for cassava production. Secondary data were obtained from existing publications of Central Bank of Nigeria, MFIs, Kogi State Agricultural Development Project, Ministry of Agriculture, Kogi State Agricultural Development Trust Fund, journals as well as other published and unpublished materials relevant to the study.

\section{Data Analysis / Analytical Framework}

The study made use of the stochastic frontier production function with maximum likelihood approach, and the translog functional form in particular. The choice of the model is because it allows the test for the presence of technical inefficiency while accepting random shocks. The Stochastic Frontier Production Function according to Coelli (1996) is stated as: $\mathrm{Yi}=\mathrm{Xi}, \beta+(\mathrm{Vi}-\mathrm{Ui})$

Where $\mathrm{Yi}$ is the logarithm of the production output of cassava of the ith farmer; $\mathrm{Xi}$ is a $\mathrm{k} \times 1$ vector of (transformation of the) input quantity of the ith farmer; $\beta \mathrm{i}$ is a vector of unknown parameters; Vi's are the usual symmetric noise associated with random variables which are not under the control of the farmers (such as rainfall, natural harzards) and which are assumed to be iid $\sim \mathrm{N}\left(0, \sigma_{\mathrm{v}}{ }^{2}\right)$, and independent of the Ui's, which are non negative random variables assumed to account for the technical inefficiency in cassava production and often assumed to be iid N $\left(0, \sigma \mathrm{u}^{2}\right)$.

The parameters estimators $(\Omega)$ and the variance of the parameters in terms of $\delta^{2}=\delta \mathrm{v}^{2}+\delta \mathrm{u}^{2}$ and $\gamma=\delta \mathrm{u}^{2} /$ $\delta^{2}$ were obtained through a maximum likelihood estimation procedure. The empirical results from the analysis indicate that the Cobb-Douglas production function is not an appropriate representation of the data, in view of the specification of the data given below. The Transcendental Logarithm (translog) model for CMFIs that is estimâtes in this study is defined by

$\ln \mathrm{Yi}=\beta_{0}+\sum_{j=1}^{4} \beta j \ln X i+\frac{1}{2} \sum_{i \geq j=1}^{4} \sum_{k}^{4} \beta j k \ln X j i \ln X k i+(V i-U i)$

Where,

$\mathrm{Y}$ is the quantity of cassava harvested for the sample farmer (in kilograms);

$\mathrm{X}_{1}$ is the total land area planted to cassava (in hectares);

$\mathrm{X}_{2}$ is the total labour (family and non family) used in cassava production (in man day);

$\mathrm{X}_{3}$ is the quantity fertilizer applied (in kilograms);

$\mathrm{X}_{4}$ is cassava stems planted (in bundles). A bundle of cassava stems (equivalent to 50 cassava stems) $=($ total land area / (inter * intra plant spacing)) / average cuttings per stem $* 50$.

\section{Technical Inefficiency Model}


$\boldsymbol{\mu} \mathbf{i}=\boldsymbol{\delta}_{0}+\sum_{j=1}^{11} \delta j M j i$

Where $\delta$ s are unknown scalar parameters to be estimated;

$\mathrm{M}_{1}=$ is the total amount of microfinance loans used in cassava production (in naira);

$\mathrm{M}_{2}=$ is the amount of deposits (savings mobilization) used in cassava production in naira;

$\mathrm{M}_{3}=$ represents training and advisory services (number of time) and

$\mathrm{M}_{4}=$ represents membership in group/co-operative (number of groups/co-operatives in which farmer belongs);

$\mathrm{M}_{5}=$ access to insurance policy ( 1 for access to insurance policy, 0 otherwise);

$\mathrm{M}_{6}=$ level micro credit accessibility (total micro credit obtained) (in naira);

$\mathrm{M}_{7}=$ age of the household head (years)

$\mathrm{M}_{8}=$ household size (in number).

$\mathbf{M}_{9}=$ experience of the head of household in cassava production (in years);

$\mathrm{M}_{10}=$ educational level of the head of household (in years);

$\mathbf{M}_{11}=$ health status of the households ( 1 for sick, 0 otherwise).

The technical efficiency of individual farm will be determined as ratio of the observed output (Yi) to the corresponding frontier output $\left(\mathrm{Yi}^{*}\right)$ given the available technology. That is,

$$
\begin{aligned}
\mathrm{TE} & =\mathrm{Yi} / \mathrm{Yi}^{*} \\
& =\mathrm{f}(\mathrm{Xi}, \beta)+\exp (\mathrm{Vi}-\mathrm{Ui}) / \mathrm{f}(\mathrm{Xi}, \beta)+\mathrm{Vi} \\
& =\exp (-\mathrm{Ui}) \text { such that } 0 \leq \mathrm{TE} \leq 1
\end{aligned}
$$

Estimates of the parameters for the stochastic frontier production function model were obtained using the computer program, FRONTIER version 4.1, written by Coelli (1996), in which the variance parameters in term of $\sigma^{2}=\sigma \mathrm{v}^{2}+\sigma \mathrm{u}^{2}$ and $\gamma=\sigma \mathrm{u}^{2} / \sigma^{2}$. Various tests of hypotheses for the parameters of the frontier model were carried out using the

generalized likelihood-ratio statistic, $\lambda$, defined as: $\lambda=\mathbf{- 2} \ln \left[\frac{L\left(H_{0}\right)}{L\left(H_{1}\right)}\right]$,

where $\mathrm{L}\left(\mathrm{H}_{0}\right)$ is the value of the likelihood function for the frontier model, in which the parameters that are stated by the appropriate hypothesis, $\mathrm{H}_{0}$, are imposed; and $\mathrm{L}\left(\mathrm{H}_{1}\right)$ is the value of the likelihood function for the general frontier model. The generalized likelihood-ratio has approximately a chi-square (or mixed chisquare) distribution. The degree of freedom is number of restricted parameters which is equals to the difference between the parameters estimated under $\mathrm{H}_{1}$ and Ho respectively if the null hypothesis is true. That is if the estimated chi-square is less than the table value, we accept Ho but rejected if otherwise.

\section{Results And Disscution}

Maximum likelihood estimates for parameters which reflect the best practice farm at the existing level of technology of the estimated translog model as defined by equation (2) and (3) are presented in table 1 and 2 : from the table the sigma squared $\delta^{2}=\delta \mathrm{v}^{2}+\delta \mathrm{u}^{2}=0.583$ and 0.005 for CMFIs before access to MFSs and CMFIs during access to MFSs. Labour and cassava stem used among CMFIs before access to MFSs were highly significant at 5\% level of probability, while Land and cassava stem were highly significant at $5 \%$ level of probability among CMFIs during access to MFSs. The estimated value for the $\gamma$ - parameters of the preferred models (translog stochastic frontier production function) are quite large ( 0.814 and 0.889 for CMFIs before access to MFSs and CMFIs during access to MFSs respectively). These values indicate that technical inefficiency is highly significant in the production activities of cassava farmers. The $\gamma$-parameters show the relative magnitude of the variance in output associated with technical efficiency. Most of the estimated coefficients of the variables for the frontier production have the expected signs. For CMFIs before access to MFSs, the coefficients of the variable inputs such as labour, fertilizers and cassava stem were positive, with labour and cassava stem being statistically significant at 5 per cent level. This implies that increasing the value of labour, fertilizers and cassava stem by $1 \%$ will increase the output of cassava by $3.337,0.285$ and 0.444 respectively. Land has an inverse relationship with the output; this could be as a result of excessive use of land relative to other inputs. The coefficients of the squares of the logarithms of labour and fertilizer were positive and statistically significant at 10 per cent level. This indicates that the translog of production function exhibits increasing marginal productivities with respect to these inputs. Meanwhile, the coefficient of the square of logarithms of land is negative but statistically significant at 5 per cent level, indicating a decreasing marginal productivity with respect to land. The coefficient of the interaction between land and fertilizer was significant at 10 per cent level, while land and cassava stem, labour and cassava stems interaction were significant at 5 per cent level. For CMFIs during access to MFSs, the coefficients of the variable inputs such as land, fertilizers and cassava stem were positive, with land and cassava stem being statistically significant at 5 per cent level. This implies that increasing the value of land, fertilizers and cassava stem by $1 \%$ will increase the output of cassava 
by $0.848,0.005$ and 0.034 respectively. Labour has an inverse relationship with the output; this could be as a result of excessive use of labour relative to other inputs. The coefficients of the squares of the logarithms of land and fertilizer were positive and statistically significant at 5 per cent level. This indicates that the translog of production function exhibits increasing marginal productivities with respect to these inputs. Meanwhile, the coefficients of the square of logarithms of labour and cassava stem are negative but statistically significant at 10 per cent level, indicating a decreasing marginal productivity with respect to labour and cassava stem. The coefficient of the interaction between land and labour, land and cassava stem and labour and cassava stem are significant at 5 per cent level, while labour and fertilizer interaction is significant at 10 per cent level.

In the inefficiency model, the negative sign of the parameters indicates that the associated variables have a positive effect and vice versa. For CMFIs before access to MFSs, farming experience and health status of the farmers' households were consistent with the a priori expectation and were also significant at 5 and 10 per cent respectively. For CMFIs during access to MFSs, the amount of microcredit used, amount of savings mobilization, group/co-operative membership, training/advisory services, insurance policy, age of the household head, family size, farming experience and education of the household head have a negative sign, implying a positive effect of increasing technical efficiency of the cassava farmers in the area. The amount of microcredit used is statistically significant at 10 per cent level, with a negative estimated coefficient. This indicates that the actual amount of microcredit used these farmers had an increasing effect of technical efficiency among the farmers. This means that farmers who never diverted the microcredit obtained but used the higher amount of microcredit for major cassava production tend to have smaller technical inefficiencies. This is presumably because farmers could buy production inputs at most appropriate times and as well have a better choice of technology when funds are available from loans. Access to insurance policy is significant at 10 per cent level. The negative coefficient for access to insurance policy indicates that farmers with high level of access to insurance policy tend to have higher level of technical efficiency. This is probably because, farmers tends to have high level of confidence since they are sure of indemnity against any form of loss or failure, such that farmers can now fully operate in good faith. The level of access to microcredit (actual loan obtained) is significant at 10 per cent level, though with a positive coefficient. This indicates an increasing effect of technical inefficiencies. This could be as a result of the fact that parts of these microcredits were diverted (fungibles) to uses other than cassava production.

The z-tests revealed a statistically significant difference in the technical efficiency between CMFIs before access to MFSs and CMFIs during access to MFSs with a z-call of 5.371 at 5\% level of significance. This means that CMFI were more efficient during access to microfinance services.

Table 1: Maximum Likelihood Estimates of Frontier Production Functions for CMFIs before access to MFSs and CMFIs during access to MFSs

\begin{tabular}{|c|c|c|c|c|c|c|c|}
\hline \multirow{3}{*}{$\begin{array}{l}\text { Translog Frontier Model } \\
\text { Variable } \\
\text { Constant }\end{array}$} & \multicolumn{7}{|c|}{ CMFIs before access to MFSs CMFIs during access to MFSs } \\
\hline & \multicolumn{7}{|c|}{ Parameter Coefficient Standard err. T-ratio Coefficient Standard err. T-ratio } \\
\hline & $\beta_{o}$ & 24.641 & 4.701 & $5.242 *$ & 3.861 & 0.166 & $23.218^{*}$ \\
\hline Ln (land) & $\beta_{1}$ & -5.469 & 1.284 & $-4.259 *$ & 0.848 & 0.072 & $11.719^{*}$ \\
\hline Ln (labour) & $\beta_{2}$ & 3.337 & 1.105 & $3.020 *$ & -0.002 & 0.063 & -0.028 \\
\hline Ln (fertilizer) & $\beta_{3}$ & 0.285 & 0.374 & 0.762 & 0.005 & 0.006 & 0.944 \\
\hline Ln (Cassava stem) & $\mathrm{B}_{4}$ & 0.444 & 0.208 & $2.135^{*}$ & 0.034 & 0.014 & $2.452 *$ \\
\hline$[\text { Ln (land) }]^{2}$ & $\mathrm{~B}_{11}$ & -0.785 & 0.283 & $-2.774 *$ & 0.107 & 0.036 & $2.991 *$ \\
\hline$[\text { Ln (labour) }]^{2}$ & $\mathrm{~B}_{22}$ & 0.123 & 0.115 & $1.070^{* * *}$ & -0.311 & 0.175 & $1.781 * *$ \\
\hline$\left[\operatorname{Ln}[(\text { fertilizer })]^{2}\right.$ & $\mathrm{B}_{33}$ & 0.216 & 0.145 & $1.490 * *$ & 0.081 & 0.027 & $2.998 *$ \\
\hline$\left[\right.$ Ln $(\text { Cassava stem) }]^{2}$ & $\mathrm{B}_{44}$ & 0.102 & 0.111 & 0.919 & -0.026 & 0.024 & $-1.113 * *$ \\
\hline$[$ Ln (land) $] *[\operatorname{Ln}$ (labour) $]$ & $\mathrm{B}_{12}$ & 0.131 & 0.172 & 0.762 & -0.174 & 0.066 & $-2.643^{*}$ \\
\hline$[\operatorname{Ln}($ land)] $* \operatorname{Ln}[($ fertilizer $)]$ & $\mathrm{B}_{13}$ & 0.219 & 0.139 & $1.576^{* *}$ & 0.019 & 0.039 & 0.471 \\
\hline$[$ Ln (land)] $*$ [Ln (Cass. Stem)] & $\mathrm{B}_{14}$ & 19.494 & 0.872 & $22.356^{*}$ & -0.598 & 0.190 & $-3.141^{*}$ \\
\hline$[$ Ln (labour)] * Ln [(fertilizer)] & $\mathrm{B}_{23}$ & -6.801 & 1.612 & $-4.219 *$ & 0.270 & 0.234 & $1.153 * *$ \\
\hline [Ln (labour)] * [Ln (Cassava stem)] & $\mathrm{B}_{24}$ & 14.784 & 0.824 & $17.941 *$ & 0.957 & 0.348 & $2.749 *$ \\
\hline Ln [(fertili.)]* [Ln (Cassava stem)] & $\mathrm{B}_{34}$ & -1.081 & 0.768 & $-1.408 * *$ & -0.150 & 0.308 & -0.486 \\
\hline \multicolumn{8}{|l|}{ Inefficiency models estimate } \\
\hline Constant & $\delta_{o}$ & 0.620 & 0.132 & $4.697 *$ & 0.198 & 0.843 & 0.235 \\
\hline Amount of Microcredit used $\left(\mathrm{M}_{1}\right)$ & $\delta_{1}$ & - & - & - & -2.561 & 2.374 & $-1.079 * *$ \\
\hline Savings mobilization $\left(\mathrm{M}_{2}\right)$ & $\delta_{2}$ & - & - & - & -3.226 & 3.358 & -0.961 \\
\hline Training \& Advisory services $\left(\mathrm{M}_{3}\right)$ & $\delta_{3}$ & - & - & - & -0.327 & 1.952 & -0.168 \\
\hline
\end{tabular}




\begin{tabular}{|l|l|l|l|l|l|l|l|}
\hline Group/Cooperative memberships( $\left.\mathrm{M}_{4}\right)$ & $\delta_{4}$ & - & - & - & -0.805 & 3.051 & -0.264 \\
\hline Access to Insurance Policy $\left(\mathrm{M}_{5}\right)$ & $\delta_{5}$ & - & - & - & -2.81 & 2.850 & $-1.004^{* *}$ \\
\hline Level of Access to Credit $\left(\mathrm{M}_{6}\right)$ & $\delta_{6}$ & - & - & - & 5.053 & 4.929 & $1.025^{* *}$ \\
\hline Age $\left(\mathrm{M}_{7}\right)$ & $\delta_{7}$ & -0.711 & 0.864 & -0.823 & -0.164 & 0.461 & -0.355 \\
\hline Household size $\left(\mathrm{M}_{8}\right)$ & $\delta_{8}$ & 0.116 & 0.137 & 0.847 & -0.345 & 0.388 & -0.890 \\
\hline Farming experience $\left(\mathrm{M}_{9}\right)$ & $\delta_{9}$ & -2.207 & 0.615 & $-3.589^{*}$ & -0.090 & 0.101 & -0.890 \\
\hline Education $\left(\mathrm{M}_{10}\right)$ & $\delta_{10}$ & 0.191 & 0.101 & $1.891^{* *}$ & -0.264 & 0.316 & -0.834 \\
\hline Health status $\left(\mathrm{M}_{11}\right)$ & $\delta_{11}$ & 0.221 & 0.185 & $1.196^{* *}$ & 0.198 & 0.843 & 0.235 \\
\hline Variance parameters & & & & & & & \\
\hline Total variance & $\delta^{2}{ }_{s}$ & 0.583 & 0.492 & $1.185^{* *}$ & 0.005 & 0.004 & $1.296^{* *}$ \\
\hline Gamma & $\Gamma$ & 0.814 & 0.012 & $67.833^{*}$ & 0.889 & 0.080 & $11.105^{*}$ \\
\hline Log-likelihood function & LLF & 231.065 & & & 247.599 & & \\
\hline likelihood ratio test & LRT & 23.241 & & & 21.362 & & \\
\hline Mean Technical Efficiency & MTE & 0.300 & & & 0.676 & & \\
\hline
\end{tabular}

* Significant at $5 \%$ level

** Significant at $10 \%$ level

Source: Computed from FRONTIER 4.1 results for field data, 2009

The individual farmer's technical efficiency obtained from the estimated stochastic frontier is presented in the frequency distribution (table 2) below. The predicted technical efficiency differs substantially among cassava farmers as it ranges from 0.101 to 0.865 with the mean technical efficiency of 0.300 for CMFIs before access to MFSs and $0.103-0.987$ with a mean technical efficiency of 0.676 for CMFIs during access to MFSs. These implied that there are potentials of about $70 \%$ for CMFIs before access to MFSs and 32.4\% for CMFIs during access to MFSs to improve the output of Cassava production.

Table 2: Technical Efficiency Estimates Ranges

Technical Efficiency Estimates for CMFIs before access to MFSs and CMFIs during access to MFSs Cassava Production

\begin{tabular}{|l|l|l|}
\hline \multirow{2}{*}{ Efficiency level } & \multicolumn{1}{|c|}{ Frequency } & \\
\cline { 2 - 3 } & CMFIs before access to MFSs & CMFIs during access to MFSs \\
\hline$\leq 0.20$ & $83(69.17)$ & $5(4.17)$ \\
\hline $0.21-0.30$ & $22(18.33)$ & $19(15.83)$ \\
\hline $0.31-0.40$ & $16(13.33)$ & $20(16.67)$ \\
\hline $0.41-0.50$ & $3(2.5)$ & $19(15.83)$ \\
\hline $0.51-0.60$ & $1(0.01)$ & $30(25)$ \\
\hline $0.61-0.70$ & $2(0.02)$ & $16(13.33)$ \\
\hline $0.71-0.80$ & $2(0.02)$ & $7(5.83)$ \\
\hline $0.81-0.90$ & $1(0.01)$ & $2(1.67)$ \\
\hline $0.91-1.00$ & $0(0)$ & $2(1.67)$ \\
\hline Total & $120(100)$ & $120(100)$ \\
\hline Mean & 0.300 & 0.676 \\
\hline Minimum & 0.101 & 0.103 \\
\hline Maximum & 0.865 & 0.987 \\
\hline
\end{tabular}

Figures in parentheses represent percentages

Source: Computed from FRONTIER 4.1 results for field data, 2009.

For the NCMFI, the maximum likelihood estimates for parameters which reflect the best practice farm at the existing level of technology of the estimated translog model as defined by equation (2) and (3) are presented in table 3: from the table the sigma squared $\delta^{2}=\delta v^{2}+\delta u^{2}=0.4933$. The estimated value for the $\gamma$ parameter of the preferred model (translog stochastic frontier production function are quite large (0.908). These values indicate that technical inefficiency is highly significant in the production activities of cassava farmers. The $\gamma$ - parameter shows the relative magnitude of the variance in output associated with technical efficiency. Most of the estimated coefficients of the variables for the frontier production have the expected signs. The coefficients of the variable inputs such as labour, fertilizers and cassava stem were positive, with land, labour and cassava stem being statistically significant at 5 per cent level. This implies that increasing the value of labour and cassava stem by $1 \%$ will increase the output of cassava by 0.299 and 0.514 respectively. Land has an inverse relationship with the output; this could be as a result of excessive use of land relative to other inputs. 
The coefficient of the squares of the logarithms of fertilizer was positive and statistically significant at 5 per cent level. This indicates that the translog of production function exhibits increasing marginal productivities with respect to these inputs. Meanwhile, the coefficient of the square of logarithms of land was negative but statistically significant at 5 per cent level, indicating a decreasing marginal productivity with respect to labour and cassava stem. The coefficient of the interaction between land and cassava stem, labour and fertilizer, labour and cassava stem as well as fertilizer and cassava stem are significant at 5 per cent level.

In the inefficiency model, the coefficients of the explanatory variables such as farming experience, formal education and health status of the farmer's households for the technical inefficiency effect model are highly significant. The negative sign for experience of the head of household means that, farmers with greater experience in cassava production tend to have smaller technical inefficiencies than those with less experience, ceteris paribus. The positive coefficient for formal schooling of the head of household indicates a decreasing effect on the technical efficiency and which could be presumably due to the high level of illiteracy among cassava farmers in the area. Health status of farmers household has a positive coefficient and statistically significant at 10 per cent level. This follows the a priori expectation that adverse health have a negative effect on the technical efficiency of farmers. That is, adverse health has an increasing effect of technical inefficiency among farmers. The coefficient of health status is $0.200(20 \%)$ implying that one per cent improvement on the health conditions of the farm household could result to $20 \%$ increase in the technical efficiency of the farmers.

The z-tests revealed a statistically significant difference in the technical efficiency between CMFIs during access to MFSs and NCMFI with a z-call of 5.444 at $5 \%$ level of significance. This means that CMFIs during access to MFIs were more efficient than the NCMFI.

Table 3: Maximum Likelihood Estimates of Frontier Production Functions for CMFIs during access to MFSs and NCMFI Cassava Farmers

\begin{tabular}{|c|c|c|c|c|c|c|c|}
\hline \multirow{2}{*}{\multicolumn{2}{|c|}{$\begin{array}{l}\text { Translog Frontier Model } \\
\text { variable }\end{array}$}} & \multicolumn{3}{|c|}{ CMFIs during access to MFSs } & \multicolumn{2}{|c|}{ NCMFI } & \\
\hline & & Coefficient & Standa1 & arr. T-ratio & Coefficie & Standc & d err. T-ratio \\
\hline Constant & $\beta_{o}$ & 3.861 & 0.166 & $23.218^{*}$ & 26.540 & 4.909 & $5.406^{*}$ \\
\hline Ln (land) & $\beta_{1}$ & 0.848 & 0.072 & $11.719^{*}$ & -6.469 & 1.095 & $-5.905^{*}$ \\
\hline Ln (labour) & $\beta_{2}$ & -0.002 & 0.063 & -0.028 & 1.337 & 0.305 & $4.386^{*}$ \\
\hline Ln (fertilizer) & $\beta_{3}$ & 0.005 & 0.006 & 0.944 & 0.295 & 0.368 & 0.800 \\
\hline Ln (Cassava stem) & $\mathrm{B}_{4}$ & 0.034 & 0.014 & $2.452^{*}$ & 0.514 & 0.118 & $4.352^{*}$ \\
\hline$\left[\operatorname{Ln}(\text { land) }]^{2}\right.$ & $\mathrm{B}_{11}$ & 0.107 & 0.036 & $2.991 *$ & -0.875 & 0.294 & $-2.970^{*}$ \\
\hline$[\mathrm{Ln} \text { (labour) }]^{2}$ & $\mathrm{~B}_{22}$ & -0.311 & 0.175 & $1.781 * *$ & 0.003 & 0.015 & 0.213 \\
\hline$\left[\operatorname{Ln}[(\text { fertilizer })]^{2}\right.$ & $\mathrm{B}_{33}$ & 0.081 & 0.027 & $2.998 * 0$ & 0.205 & 0.047 & $4.398^{*}$ \\
\hline$[\text { Ln (Cassava stem) }]^{2}$ & $\mathrm{~B}_{44}$ & -0.026 & 0.024 & $-1.113 * *$ & -0.051 & 0.058 & -0.879 \\
\hline [Ln (land)] * [Ln (labour)] & $\mathrm{B}_{12}$ & -0.174 & 0.066 & $-2.643^{*}$ & 0.031 & 0.075 & 0.414 \\
\hline$[\operatorname{Ln}($ land $)] * \operatorname{Ln}[($ fertilizer $)]$ & $\mathrm{B}_{13}$ & 0.019 & 0.039 & 0.471 & 0.019 & 0.039 & 0.471 \\
\hline$[$ Ln (land)] $*[$ Ln (Cass. Stem)] & $\mathrm{B}_{14}$ & -0.598 & 0.190 & $-3.141^{*}$ & 22.494 & 0.978 & $23.009^{*}$ \\
\hline$[\operatorname{Ln}($ labour)] $*$ Ln [(fertilizer)] & $\mathrm{B}_{23}$ & 0.270 & 0.234 & $1.153^{* * *}$ & -7.208 & 0.667 & $-10.815^{*}$ \\
\hline$[$ Ln (labour)] $*[$ Ln (Cassava stem)] & $\mathrm{B}_{24}$ & 0.957 & 0.348 & $2.749 *$ & 16.894 & 0.972 & $17.386^{*}$ \\
\hline $\operatorname{Ln}[($ fertili.) $] *[\operatorname{Ln}($ Cassava stem) $]$ & $\mathrm{B}_{34}$ & -0.150 & 0.308 & -0.486 & -2.081 & 0.787 & $-2.643^{*}$ \\
\hline \multicolumn{8}{|l|}{ Inefficiency model estimate } \\
\hline Constant & $\delta_{o}$ & 0.198 & 0.843 & 0.235 & 0.710 & 0.127 & $5.616^{*}$ \\
\hline Amount of Microcredit used $\left(\mathrm{M}_{1}\right)$ & $\delta_{1}$ & -2.561 & 2.374 & $-1.079 * *$ & - & - & - \\
\hline Savings mobilization $\left(\mathrm{M}_{2}\right)$ & $\delta_{2}$ & -3.226 & 3.358 & -0.961 & - & - & - \\
\hline Training \& Advisory services $\left(\mathrm{M}_{3}\right)$ & $\delta_{3}$ & -0.327 & 1.952 & -0.168 & - & - & - \\
\hline Group/Cooperative memberships $\left(\mathrm{M}_{4}\right)$ & $\delta_{4}$ & -0.805 & 3.051 & -0.264 & - & - & - \\
\hline Access to Insurance Policy $\left(\mathrm{M}_{5}\right)$ & $\delta_{5}$ & -2.81 & 2.850 & $-1.004 * *$ & - & - & - \\
\hline Level of Access to Credit $\left(\mathrm{M}_{6}\right)$ & $\delta_{6}$ & 5.053 & 4.929 & $1.025 * *$ & - & - & - \\
\hline Age $\left(M_{7}\right)$ & $\delta_{7}$ & -0.164 & 0.461 & -0.355 & -0.605 & 0.874 & -0.692 \\
\hline Household size $\left(\mathrm{M}_{8}\right)$ & $\delta_{8}$ & -0.345 & 0.388 & -0.890 & 0.006 & 0.009 & 0.666 \\
\hline Farming experience $\left(\mathrm{M}_{9}\right)$ & $\delta_{9}$ & -0.090 & 0.101 & -0.890 & -2.109 & 0.512 & $-4.118^{*}$ \\
\hline Education $\left(\mathrm{M}_{10}\right)$ & $\delta_{10}$ & -0.264 & 0.316 & -0.834 & 0.241 & 0.143 & $1.687 * *$ \\
\hline
\end{tabular}




\begin{tabular}{|l|l|l|l|l|l|l|l|}
\hline Health status $\left(\mathrm{M}_{11}\right)$ & $\delta_{11}$ & 0.198 & 0.843 & 0.235 & 0.200 & 0.196 & $1.022^{* *}$ \\
\hline Variance parameters & & & & & & & \\
\hline Total variance & $\delta^{2}{ }_{s}$ & 0.005 & 0.004 & $1.296^{* *}$ & 0.4933 & 0.484 & $1.020^{* *}$ \\
\hline Gamma & $\Gamma$ & 0.889 & 0.080 & $11.105^{*}$ & 0.903 & 0.001 & $11070.11^{*}$ \\
\hline Log-likelihood function & LLF & $\begin{array}{l}247.59 \\
9\end{array}$ & & & $\begin{array}{l}225.06 \\
5\end{array}$ & & \\
\hline Likelihood ratio test & LRT & 21.362 & & & 21.362 & & \\
\hline Mean Technical Efficiency & MTE & 0.68 & & & 0.33 & & \\
\hline
\end{tabular}

* Significant at $5 \%$ level

** Significant at $10 \%$ level

Source: Computed from FRONTIER 4.1 results for field data, 2009

The individual farmer's technical efficiency obtained from the estimated stochastic frontier is presented in the frequency distribution (table 4) below. The predicted technical efficiency differs substantially among cassava farmers as it ranges from $0.10-0.57$ with a mean technical efficiency of 0.33 , on the scale of 1.00 . This implies that there is a potential of about $67 \%$ to improve the output of the farmers

Table 4: Technical Efficiency Estimates Ranges

Technical Efficiency Estimates for CMFIs during access to MFSs and NCMFI Cassava Production

\begin{tabular}{|l|l|l|}
\hline \multirow{2}{*}{ Efficiency level } & \multicolumn{1}{|c|}{ Frequency } & \\
\cline { 2 - 3 } & CMFIs during access to MFSs & NCMFI \\
\hline$\leq 0.20$ & $5(4.17)$ & $71(59.17)$ \\
\hline $0.21-0.30$ & $19(15.83)$ & $26(21.67)$ \\
\hline $0.31-0.40$ & $20(16.67)$ & $19(15.83)$ \\
\hline $0.41-0.50$ & $19(15.83)$ & $3(2.5)$ \\
\hline $0.51-0.60$ & $30(25)$ & $1(0.01)$ \\
\hline $0.61-0.70$ & $16(13.33)$ & $0(0)$ \\
\hline $0.71-0.80$ & $7(5.83)$ & $0(0)$ \\
\hline $0.81-0.90$ & $2(1.67)$ & $0(0)$ \\
\hline $0.91-1.00$ & $2(1.67)$ & $0(0)$ \\
\hline Total & $120(100)$ & $120(100)$ \\
\hline Mean & 0.676 & 0.333 \\
\hline Minimum & 0.103 & 0.100 \\
\hline Maximum & 0.987 & 0.565 \\
\hline
\end{tabular}

Figures in parentheses represent percentages

Source: Computed from FRONTIER 4.1 results for field data, 2009.

\section{Conclusions And Policy Implications}

A translog non-neutral stochastic frontier production function was used in this study. The results show that the most significant variables explaining the variations in cassava production are land and cassava stem. The z-tests revealed statistically significant differences in the technical efficiency between CMFIs before access to MFSs and CMFIs during access to MFSs as well as between CMFIs during access to MFSs and NCMFI with z-cal of 5.371 and 5.444 at 5\% level of significance respectively. This means that CMFI cassava farmers were more efficient during access to microfinance services and as well more efficient than the NCMFI. The technical efficiencies of production of farmers are significantly related to the amount of microcredit used for major cassava production and access to insurance policy. Therefore, agricultural policy makers should focus on the factors affecting the efficiency of farmers including improving and increasing the number of rural financial institutions and improving the borrowing conditions so that farmers can avail themselves of loans to assist in their major cassava production operations. Insurance policies, which would encourage farmers to build confidence should be encouraged and made accessible to farmers in the rural areas. The government should stimulate and motivate farmers to adopt new agricultural technology such as high yielding varieties of cassava and modern agricultural machinery. Meanwhile, effort should be made government and financial NGOs to avoid diversion of agricultural loans. Also, the interest drawback policy of government in which all honest farmers and borrowers who repay their loans on schedule will enjoy an interest rebate of 40 per cent of total interest paid on the loan should be intensified.

\section{References}

[1]. Abdulai, A and W.E. Huffman (1998). "An Examination of Profit Inefficiency of Rice Farmers inNorthernGhana".Staff Paper No. 296, Department of Economics, Iowa State University.

[2]. Akiram,W. et al (2008). “Agricultural Credit Constraints and Borrowing Behavior of Farmers in Rural Punjab”. European Journals of Scienctific Research ISSN 1450- 216X Vol.23 No.2 (2008), pp.294-304 
[3]. Antonio, C.A. (2002). Cassava Biology, Production and Utilization: The Origin and Taxonomy of Cassava. CABI Publishing; Brazil. Pp. 1-343.

[4]. Arene, C.J (2008). Agricultural Economics: A Functional approach. Price publisher, Nsukka, Nigeria. Pp. 65-100.

[5]. CBN(2004) in: Nweke, F. (2004). "New Challenges in Cassava Transformation in Nigeria and Ghana". Discussion papers No.118. Environmental and Production Technology Division, International Food Policy Research, Washington D.C 2006, USA.

[6]. Chaovanapoonphol, Y. et al, (2005). "The Impact of Rural Financial Services on the technical Efficiency of Rice Farmers in the Upper North of Thailand". Annual Conference of the Australian Agriculture and Resource Economics Society. Coffs Harber, 2005. Pp.1-16.

[7]. Coelli, T.J. (1996). "A Guide to Frontier Version 4.1: A Computer Program for Stochastic Frontier Production Function and Cost Function Estimation," Working Paper in Centre for Productivity and Efficiency Analysis.Development of Econometrics, University of New England Armidale, NSW 2351, Australia. Retrievedon $5^{\text {th }}$ march, 2007 from http://www.une.edu.au/econometrics/cepawp.

[8]. Ezedinma, C. et al (2006). "Trends in Farm Labour Productivity and Implications for Cassava Industrialization in Nigeria". Proceedings of the $40^{\text {th }}$ conference of the Agricultural Society of Nigeria, Abia. P.p. $109-115$.

[9]. FAO (1995). Post Harvest Deterioration of Cassava. Retrieved on $20^{\text {th }}$ December, 2008, From http:// www. fao.org/ docrep/ v4510e/ V4510E02.htm

[10]. FAO (2002). Partnership Formed to improve Cassava, Staple Food of 600 Million People. Retrieved on $10^{\text {th }}$ August, 2008 from

[11]. http://www.fao.org/english/newsroom/news/2002/10541-en.html

[12]. FAOSTAT (2008). Statistical Data Base Division: Crop Production Output and Land Area Planted. Retrieved on15 ${ }^{\text {th }}$ July, 2008 from http://www.fao.org/

[13]. Food Agricultural Organization Statistics (FAOSTAT)(2005). Food and Agricultural Data Base.

[14]. IFAD (2007). The role Rural Finance in Livestock Development. Retrieved on $4^{\text {th }}$ July, 2008 from http:// www .ifad.org/ lrkm/ range/credit.htm

[15]. IFAD and FAO (2004). "The Global Cassava Development Strategy". A Cassava Industrial Revolution in Nigeria: The Potential for a New Industrial Crop.

[16]. International Food Policy Research Institute (IFPRI) (2001) in: Alabi, R.A and D.I. Oviasogie (2005). "Cassava Production and Processing in Nigeria: Opportunities and Challenges". Proceedings of the $39^{\text {th }}$ Conference of Agricultural Society of Nigeria, Benin, 2005 .

[17]. International Institute for Tropical Agriculture (IITA) (2004). Nigeria's Cassava Industry: Statistical Hand Book.

[18]. Kogi State Agricultural Development Project (KSADP) (1995). A Colossus in Agricultural Transformation. Pp I-6.

[19]. Kogi State Agricultural Development Trust Fund (KSADTF) (2007). Unpublished Data of Microfinance Loans issued to Farmers, in Kogi State.

[20]. Kohansal, M. R., M. Ghorbani and H. Mansoori (2008). "Effect of Credit Accessibility of Farmers on Agricultural Investiment and Investigation of Policy Options in Khorasan-Razavi Province". Journal of Applied Sciences. 8 (23): 4455-4459, 2008

[21]. KSADP (2007). Unpublished data on Cassava Output and Cultivated Land. Obtained from KSADP Headquarters, Lokoja

[22]. Nigeria Agricultural Cooperatives and Rural Development Banks (NACRDB) (2002). Brochure. Pp.1-16.

[23]. Nigerian Population Commission (2006). Preliminary 2006 Census figures. Retrieved September, 2007 from http:// www. population. gov.ng/pop figure.pdf

[24]. Olayide, S. O. and E.O. Heady (1982). Introduction to Agricultural Production Economics. Ibadan: Ibadan University Press.

[25]. Oyewole, O.B and Phillips, B (2006). "Agro-Food Chain and Sustainable Livelihood: A Case of Cassava Marketing In Nigeria". Research and Development Centre (RESDEC), University of Agriculture, Abeokuta, Nigeria. Retrieved on $20^{\text {th }}$ September, 2008 from http://library.wur.nl/frontis/agro-food_chains/09_oyewole.pdf

[26]. Pederson, G. (2003). "Rural Financial Institutions, Markets and Policies in Africa". Paper Presented at Pre-IAAE Conference in African Agricultural Economics, Bloemfontein, South Africa. Pp1-25.

[27]. Philips, T. P. et al (2004). A Cassava Revolution in Nigeria: Potential for new Crop

[28]. Prakash, A (2007) Cassava: International Market Profile. Background paper for the Competitive Commercial Agriculture in SubSaharan Africa (CCAA) Study, Trade and Markets Division, Food and Agriculture Organisation of the United Nations. Retrieved on $2^{\text {nd }}$ October, 2008 from

[29]. http://siteresources.worldbank.org/INTAFRICA/Resources/257994-1215457178567/Cassava_Profile.pdf

[30]. Project Coordinating Unit (PCU) (2003). Crop Area Yield Survey. Abuja, Nigeria. Federal Ministry of Agriculture and Rural Development.

[31]. Qayyum, A. and M. Ahmed (2006). "Efficiency of MFIs in South Asia”.Pakistan Institute of Development Economics, Pakistan. Pp. 1 - 37.

[32]. SMEC, 2008. Venture Financing: Microfinance and Cassava Partnership for Rural Development. Retrieved on $17^{\text {th }}$ July, 2008 from

[33]. http.//www.smeclub.net/smecommunity/modules

[34]. Syngenta Foundation for Sustainable Agriculture (2008). The Role Microfinance In Rural Micro enterprise Development. Retrieved on $17^{\text {th }}$ September, 2008 from http://www.syngentafoundation.org/microfinance_rural_enterprenuer.htm

[35]. United Nation International Fund for Agricultural Development (2005). Small Loans Makes a big Difference”. Spore publication. 118: August, 2005 